\title{
Estimation of Carbon Sequestration Potential of Urban Trees in Educational Institution: With Special Reference to Guru Gobind Singh Indraprastha University Campus, Delhi, India
}

\author{
Anand Mr ( $\square$ aanandkr344@gmail.com ) \\ Guru Gobind Singh Indraprastha University https://orcid.org/0000-0002-4858-9358 \\ Gunjan Som \\ Guru Gobind Singh Indraprastha University \\ Prodyut Bhattacharya \\ Guru Gobind Singh Indraprastha University
}

Research Article

Keywords: Carbon Sequestration, Urban Trees, Standing Biomass, Non-destructive Method, Educational Institutions.

Posted Date: May 5th, 2021

DOI: https://doi.org/10.21203/rs.3.rs-463791/v1

License: (c) (i) This work is licensed under a Creative Commons Attribution 4.0 International License. Read Full License 


\section{Abstract}

Trees assimilate the atmospheric carbon through photosynthesis that stores tremendous $\mathrm{CO}_{2}$ from the atmosphere in biomass. Urban trees play a significant role in accumulating atmospheric $\mathrm{CO}_{2}$ in biomass and hence help climate change mitigation and biodiversity conservation. The study carried out on the campus of GGS IP University, Dwarka, Delhi. The living biomass stored in the trees of the campus calculated using allometric equations. The total area of campus is 60.436 acres that have 1657 trees in number. The diameter at Breast Height (DBH) of each tree was measured. The results reveal that Total Biomass and Carbon Stored are 248.29 tons and 124.14 tons, respectively. There is a total of 40 different species belonging to 21 families. Ficus virens is the dominant species followed by Ficus benjamina and Putranjiva roxburghii, respectively. In order to increase the carbon sinks, it is necessary to carry out the afforestation periodically. Therefore, a similar carbon sequestration study is required every ten years for green space planning, which is crucial in keeping ecosystem services optimal for the University Campus or educational institutes.

\section{Introduction}

Urban Green Spaces (UGSs), i.e., parks, gardens, avenue plantations, campus areas, uninhabited land and nature trails within the forests, provide indispensable Ecosystem Services (ESs) for the residents living in urban areas (McDonald and Marcotullio 2011; Cameron and Blanusa 2016; Elmqvist et al., 2015). The basis on earlier categorizations of ESs given by the Millennium Ecosystem Assessment (MEA 2005), The Economics of Ecosystem Services and Biodiversity (TEEB 2010) and Common International Classification of Ecosystem Services (Haines-Young, R. and M.B. Potschin 2018) arranged ESs in four divisions, i.e., provision, regulating, habitat, cultural and amenity services. UGSs generate provision services like food and freshwater (Bagdon et al., 2016; Alamgir et al., 2016), regulating services like air purification, microclimate regulation, carbon sequestration (Forman 2014; Nowak et al., 2006; Selmi et al., 2016), habitat services like home for biodiversity (Bagdon et al., 2016) and cultural services like recreation and health, environmental education (Chiesura 2004; Andersson et al., 2015).

UGSs are growing more than the population that is rapidly increasing in urban areas in the current decade (Fuller and Gaston 2009; Seto et al., 2012). Therefore, it is vital to assess and quantify UGS ES. In the recent decade, many studies have been conducted to calculate the ES of urban forests (Nowak et al., 2013a; Liu and Li 2012; Nowak et al., 2002a), urban trees (Tang et al., 2016; Russo et al., 2014), urban parks and gardens (Buchel and Frantzeskaki 2015; Langemeyer et al., 2015; Breuste and Artmann 2015; Speak et al., 2015; Camps-Calvet et al., 2016), campuses (Hepcan and Hepcan 2018; Vishnu and Patil 2016).

Many methodologies have been developed to calculate ES around the globe by researchers such as InVEST (Integrated Valuation of Ecosystem Services and Tradeoffs), UFORE (Urban Forest Effects Model), CUFR Tree Carbon Calculator (CTCC) and i-tree Eco ( Tallis et al., 2011; CUFR, 2008; Pickard et al., 2015; USDA Forest Service, 2015). 
Numerous researches (Liu and Li 2012; Park et al., 2018; Russo et al., 2014; Hepcan and Hepcan 2018; Sun et al., 2019; Nowak and Crane 2002) have explained that urban trees remove carbon dioxide from the atmosphere through the process of photosynthesis and store excess carbon as biomass in stems and roots. Indirectly, urban trees also help to reduce the energy demands of the building by providing shade and climate amelioration influences, thereby reducing $\mathrm{CO}_{2}$ emissions from lowered energy production (Akbari et al., 2001). Carbon sequestration is one of the regulating services of the Ecosystem. Vegetation has been widely tabulated in different categories according to the capacity of generating provisioning (water and food production), regulating (climate change mitigation and carbon sequestration), supporting (Nutrient Cycle) and cultural (aesthetic benefits) ecosystem services (MEA, 2005). Most of the carbon storage and sequestration studies have been conducted in the United States (Rowntree and Nowak 1991; Nowak 1993, 1994; Jo and McPherson 1995; McPherson et al., 1997, 1999; McPherson 1998; Myeong et al., 2006; Mchale et al., 2007, 2009, Escobedo et al., 2010). Despite this, there is an increasing interest in the quantification of carbon storage and sequestration by urban forests in both developing and developed nations (Brack 2002; Jo 2002; Yang et al., 2005; Gratani and Varone 2006; Myeong et al., 2006; Stoffberg et al., 2010; Zhao et al., 2010).

Guru Gobind Singh Indraprastha University situated in the southwest of Delhi, where the population is $2,292,958$ and population density is 5,446 per $\mathrm{km}^{2}$. During 2001-2011, southwestern Delhi recorded the highest growth rate of $30.65 \%$ compared to other city districts. Urban population is increasing rapidly, putting enormous pressure on existing green spaces, resulting in a decrease of green cover and degradation of ecosystem services. It has become imperative to estimate carbon storage and sequestration to assess the potential role of urban forests within the city. Such studies highlight the role of tree cover in carbon sequestration and emphasize the need for greater attention towards selecting trees in educational institutions, which supports biodiversity and maximizes environmental services.

\section{Study Area}

\subsection{Delhi: Statistics}

The present study was conducted at Guru Gobind Singh Indraprastha University (GGS IPU) campus $\left(28^{\circ} 35^{\prime} 41.94^{\prime \prime} \mathrm{N}\right.$ and $\left.77^{\circ} 1^{\prime} 9.59 " \mathrm{E}\right)$, Dwarka, Delhi, located at the southwest of Delhi. The total area of GGSIPU campus is 60.436 acres (Fig. 1). Delhi, the capital of India, has an area of $1483 \mathrm{sq} \mathrm{km}$, which is $0.05 \%$ of India's geographical area. Delhi lies between $28^{\circ} 22^{\prime} \mathrm{N}$ to $28^{\circ} 54^{\prime} \mathrm{N}$ latitude and $76^{\circ} 48^{\prime} \mathrm{E}$ to $77^{\circ} 23^{\prime} \mathrm{E}$ longitude and shares its boundaries with Haryana and Uttar Pradesh. The altitudes of Delhi ranges from $180 \mathrm{~m}$ to $316 \mathrm{~m}$ above mean sea level. Delhi receives rainfall from $400 \mathrm{~mm}$ to $600 \mathrm{~mm}$ annually. The annual temperature ranges from $3^{\circ} \mathrm{C}$ to $45^{\circ} \mathrm{C}$. Delhi has 11 districts and none, neither hill nor tribal. According to Census 2011, the population of Delhi is 16.79 million, out of which $97.25 \%$ is urban, and $2.50 \%$ is rural. Delhi has a population density of 11,320 people per kilometre.

\subsection{Delhi: Urban Green Space Status}


According to India State of Forest Report 2019, forest cover in the Delhi is 195.44 sq $\mathrm{km}$ which is $13.18 \%$ of Delhi's total area. Table 1 shows the distribution of forest class and area covered by these classes in the state.

The Forest Department under Delhi government administers and promote conservation activities to promote and encourage the participation of public educational institutes and carries out "Greening Delhi Campaign" every year. In Delhi, there is no forest land conversion to non-forestry purposes under the Forest Conservation Act, 1980 in the last four years (MoEF \& CC, 2019).

Apart from forest cover, Delhi has a significant number of parks and gardens. Delhi has more than 18,000 parks and gardens with about 8000 ha in different locations throughout Delhi. These parks, gardens, avenue plantations etc., are potential sites to enhance green cover within the state without the demand for extra land. These green spaces are managed by different department like CPWD, PWD, MCD, DDA, RWA etc.

To manage the parks and gardens in the state, the Delhi government has formed a society, namely Delhi Parks and Garden Society, to coordinate with the different department within the state and ensure the proper maintenance of the parks and gardens.

\section{Materials And Method}

GGSIPU campus map was obtained with the help of Google Earth. Tree census was done on the campus in February 2019, and tree data, i.e. GBH (Girth at Breast Height) and diameter of each tree, was measured at $1.37 \mathrm{~m}$ (approx $4.5 \mathrm{ft}$ ) above the ground using a measuring tape to get $\mathrm{GBH}$ of each tree. The methodology is to enumerate the total number of trees within the GGSIPU campus and measure the diameter at breast height (DBH) to estimate carbon sequestration potential. The sample comprised 'trees' as defined by the Delhi Preservation of Tree Act, 1994. According to the Delhi Preservation of Tree Act, 1994 under Sect. 2(i) 'a "tree" means any woody plant whose branches spring from and are supported upon a trunk or body is not less than five centimeters in diameter at a height of thirty centimeters from the ground level and is not less than one meter in height from the ground level'. Trees that fell under the above act only considered.

\subsection{Carbon Storage and sequestration}

The process by which trees remove the carbon from the atmosphere is called carbon sequestration. The amount or weight of carbon accumulated by a tree is called carbon storage (Nowak et al., 2012). Carbon store in a tree is directly proportional to its biomass, increasing its diameter, height, and canopy spread (McPherson 1998). The amount of carbon sequestration depends on the growth characteristics of the tree species, the condition for growth where the tree is planted and the density of the tree's wood (Jana et al., 2010).

There are many methods to estimate carbon sequestration and storage. In most of the methods and models, different attributes of an individual tree are considered age, DBH, height, tree species and geographic location. In this research, carbon sequestration and storage were calculated by using the nondestructive method, i.e. Allometric Equations; (1) calculated AGB and BGB of the trees, (2) Estimated Total 
biomass of the trees (TB), (3) Estimated Carbon Storage (CS) of the trees. Equations are given below in Table 2, where $\mathrm{D}$ is $\mathrm{DBH}$ in $\mathrm{cm}$.

\section{Results \& Discussion}

\subsection{Structure of GGS IP University Campus's Trees}

A total of 1657 trees that belong to 40 species from 21 families were measured. The dominant species is Ficus virens which has 569 individuals and accounts for $34.33 \%$ of the total tree population. The second and third most common species are Ficus benjamina and Putranjiva roxburghii, respectively. The campus has 812 deciduous and 845 evergreen, which represents 21 families. $93.60 \%$ of trees are native and $5.01 \%$ and $1.39 \%$ are introduced and naturalized, respectively. The largest DBH is recorded in Ficus benghalensis measured $280 \mathrm{~cm}$ followed by Ficus religiosa measured $264 \mathrm{~cm}$. These dominant species are very common to urban plantation as these can survive drought conditions, not require any specific soil type and significantly less maintenance.

Out of the total tree population, $93.60 \%$ are native, and $5.01 \%$ and $1.39 \%$ are introduced and naturalized respectively. According to tree census of the GGS IP University campus suggested that $63.55 \%(1053)$ trees belong to $0-50 \mathrm{~cm}$ category and $31.38 \%(520), 4.04 \%(67), 0.60 \%(10)$ and $0.42 \%(07)$ to following category $50-100,100-150,150-200$ and $>200$ respectively. This data shows tree population is very young and has great carbon sequestration potential. Generally, at an early stage or smaller DBH, trees sequester more carbon and larger tree store more carbon than small or young trees (Nowak, 1994).

\subsection{Carbon Storage and Sequestration of GGS IP University Campus}

To acknowledge research question, results showed that total biomass and total carbon stored in GGSIP University campus is 248.29 tons and 124.14 tons, respectively. Total biomass stored by evergreen and deciduous trees is $46.01 \%$ (114.23t), 53.99\% (134.05t), respectively (Fig. 4). Similarly, total carbon stored by evergreen and deciduous trees is $46.01 \%(57.11 t), 53.99 \%$ (67.02t), respectively. Family Moraceae found to be the dominant family, followed by Putranjivaceae and Bombacaceae.

Characteristics like species type, age, growth pattern, rainfall and most importantly, geographical conditions affect the carbon storage and sequestration potential. Thus, it is very challenging to compare the results of different studies (Aguaron and McPherson, 2012). The alike study was conducted at Amity University, Noida and published that the total carbon sequestered by all the trees in a year is 139.9 tons (Sharma et al., 2020).

Table 1 shows that the carbon sequestered by each trees species within the GGS IP University campus. The above and below ground biomass 215.89 tons and 32.37 tons, respectively.

\section{Conclusion}


Urban Trees play an important role in moderating climate change by sequestering or reducing atmospheric carbon. Hence, it is crucial to estimate the potential of carbon sequestration and storage of urban forests or trees. This research primarily provides a case study of the estimation of carbon sequestration and storage potential of urban trees planted in educational institutes situated in urban areas. Regulating ES is one of the most critical functions of green spaces. There is it essential to assess and map ES in planning a smart city or green space management.

Horticulture department of the GGS IP University taking care of the green spaces within the campus. These green spaces provide a learning environment to students and faculty and space for recreational activities. However, adjacent colonies to campus do not have access to these green spaces but still experience many benefits.

It is essential to accurately measure Carbon Storage and Sequestration values of urban trees therefore, site and species-specific allometric equations needed. More studies to be conducted to develop an allometric equation and monitor Urban ES provided by trees to understand the role of trees in Carbon Sequestration and storage.

\section{Declarations}

\section{Acknowledgement}

We would like to thank everyone who helped during this research article, especially Prof. Prodyut Bhattacharya, as this research article would not have been written without his support.

\section{Conflict of interest}

All authors declare that they have no conflict of interests.

\section{Funding Agency}

University Grants Commission, India for providing funds for the research work.

\section{Availability of data and material}

Not Applicable

Code Availability

Not Applicable

\section{Author's Contributions}

Not Applicable

\section{Ethics Approval}


Not Applicable

\section{Consent to Participate}

Not Applicable

\section{Consent for publication}

Not Applicable

\section{References}

1. Aguaron, E., McPherson, E.G., 2012. Comparison of methods for estimating carbon dioxide. In: Lal, R., Augustin, B. (Eds.), Carbon Sequestration in Urban Ecosystems, pp. 373-383. http://dx.doi.org/10.1007/978-94-007-2366-5_3.

2. Akbari H, Pomerantz M, Taha H (2001) Cool surfaces and shade trees to reduce energy use and improve air quality in urban areas. Sol Energy 70:295-310

3. Alamgir, M., Turton, S.M., Macgregor, C.J., Pert, P.L., 2016. Assessing regulating and provisioning ecosystem services in a contrasting tropical forest landscape. Ecol. Indic. 64, 319-334.

4. Andersson, E., McPhearson, T., Kremer, P., Gomez-Baggethun, E., Haase, D., Tuvendal, M., Wurster, D., 2015. Scale and context dependence of ecosystem services providing units. Ecosyst. Serv. 12, 157164.

5. Bagdon, B.A., Huang, C.H., Dewhurst, S., 2016. Managing for ecosystem services in northern Arizona ponderosa pine forests using a novel simulation-to-optimization methodology. Ecol. Modell. 324, 1127. http://dx.doi.org/10.1016/j.ecolmodel. 2015.12.012.

6. Brack, C.L., 2002. Pollution mitigation and carbon sequestration by an urban forest. Environmental Pollution 116, 195-200.

7. Breuste, J., Artmann, M., 2015. Allotment gardens contribute to urban ecosystem service: case study Salzburg, Austria. J. Urban Plann. Dev. 141 (3) (A5014005-1- A5014005-10).

8. Buchel, S., Frantzeskaki, N., 2015. Citizens' voice: a case study about perceived ecosystem services by urban park users in Rotterdam, The Netherlands. Ecosyst. Serv. 12, 169-177.

9. Cameron, R.W.F., Blanusa, T., 2016. Green infrastructure and ecosystem services - is the devil in the detail? Ann. Bot. 118, 377-391. http://dx.doi.org/10.1093/aob/mcw129.

10. Camps-Calvet, M., Langemeyer, J., Calvet-Mir, L., Gomez-Baggethun, E., 2016. Ecosystem services provided by urban gardens in Barcelona, Spain: insights for policy and planning. Environ. Sci. Policy 62, 14-23. http://dx.doi.org/10.1016/j.envsci.2016. 01.007.

11. Chiesura, A., 2004. The role of urban parks for the sustainable city. Landscape Urban Plann. 68 (1), 129-138. http://dx.doi.org/10.1016/j. Landurbplan.2003.08.003.

12. Coskun Hepcan, C., \& Hepcan, S. (2018). Assessing regulating ecosystem services provided by the Ege University Rectorship Garden. Urban Forestry and Urban Greening, 34, 10-16. 
https://doi.org/10.1016/j.ufug.2018.05.011

13. CUFR, 2008. CUFR Tree Carbon Calculator (CTCC). http://www.fs.fed.us/ccrc/topics/urbanforests/ctcc/, (Accessed 08 December 2019).

14. Elmqvist, T., Setala, H., Handel, S.N., Van der Ploeg, S., Aronson, J., Blignaut, J.N., Gomez-Baggethun, E., Nowak, D.J., Kronenberg, J., de Groot, R., 2015. Benefits of restoring ecosystem services in urban areas. Curr. Opin. Environ. Sustain. 14, 101-108. http://dx.doi.org/10.1016/j.cosust.2015.05.001.

15. Escobedo, F., Varela, S., Zhao, M., Wagner, J.E., Zipperer, W., 2010. Analyzing the efficacy of subtropical urban forests in offsetting carbon emissions from cities. Environmental Science and Policy 13, 362372.

16. Forman, R.T.T., 2014. Urban Ecology Science of Cities. University Press, Cambridge, pp. 462 (ISBN-13: 978-052118824).

17. FSI, (2019). India State of Forest Report 2019, Forest Survey of India, Dehradun, India

18. Fuller, R.A., and K.G. Gaston. 2009. The scaling of green space coverage in European cities. Biology Letters 5: 352-355.

19. Gratani, L., Varone, L., 2006. Carbon sequestration by Quercus ilex L. and Quercus pubescens Willd. and their contribution to decreasing air temperature in Rome. Urban Ecosystems 9, 27-37.

20. Haines-Young, R. and M.B. Potschin (2018): Common International Classification of Ecosystem Services (CICES) V5.1 and Guidance on the Application of the Revised Structure.

21. Jana B.K., Biswas S., Majumder M., Roy P., Mazumdar A. (2010) Accumulation of Carbon Stock Through Plantation in Urban Area. In: Jana B., Majumder M. (eds) Impact of Climate Change on Natural Resource Management. Springer, Dordrecht. https://doi.org/10.1007/978-90-481-3581-3_15

22. Jeong Ho Park, Saeng Geul Baek, Min Young Kwon, Sun Mi Je \& Su Young Woo (2018) Volumetric equation development and carbon storage estimation of urban forest in Daejeon, Korea, Forest Science and Technology, 14:2, 97-104, DOI: 10.1080/21580103.2018.1452799.

23. Jo, H.K., 2002. Impacts of urban greenspace on offsetting carbon emissions for middle Korea. Journal of Environmental Management 64, 115-126.

24. Jo, H. K., \& McPherson, G. E. (1995). Carbon storage and flux in urban residential greenspace. Journal of Environmental Management, 45, 109-133.

25. Langemeyer, J., Baro, F., Roebeling, P., Gomez-Baggethun, E., 2015. Contrasting values of cultural ecosystem services in urban areas: the case of park Montjuic in Barcelona. Ecosyst. Serv. 12, 178186.

26. Liu, C., \& Li, X. (2012). Carbon storage and sequestration by urban forests in Shenyang, China. Urban Forestry \& Urban Greening, 11(2), 121-128.

27. McDonald, R., \& Marcotullio, P. (2011). Global effects of urbanization on ecosystem services. In J. H. Breuste, G. Guntenspergen, N. E. Mclntyre, et al. (Eds.), Urban ecology: Patterns, pro- cesses, and applications . Oxford: Oxford University Press.

28. McHale, M. R. et al. (2009) 'Urban Forest Biomass Estimates: is It Important to Use Allometric Relationships Developed Specifically for Urban Trees?', Urban Ecosystems, 12: 95-113. 
29. McHale, M.R., E.G. McPherson, and I.C. Burke. 2007. The potential of urban tree plantings to be cost effective in carbon credit markets. Urban Forestry \& Urban Greening 6: 49-60.

30. McPherson, E. G., \& Simpson, J. R. (1999). Carbon dioxide reduction through urban forestry: Guidelines for professional and volunteer tree planters. USDA Forest Service Pacifi c Southwest Research Station General Technical Report PSW-GTR-171, Berkeley, CA.

31. McPherson, E. G. (1998). Atmospheric carbon dioxide reduction by Sacramento's urban forest. Journal of Arboriculture, $24,215-223$.

32. McPherson, E.G. 1998. Structure and sustainability of Sacramento's urban forest. Journal of Arboriculture. 24(4): 174-190.

33. McPherson, E. G., Nowak, D., Heisler, G., et al. (1997). Quantifying urban forest structure, function, and value: The Chicago urban forest climate project. Urban Ecosystems, 1 (1), 49-61.

34. MEA. (2005). Millennium ecosystem assessment: Ecosystems and human well-being: Synthesis.

35. Washington, DC: Island Press.

36. Nowak, D.J., 1993. Atmospheric carbon reduction by urban trees. Journal of Environ- mental Management 37, 207-217.

37. Nowak, D.J., 1994. Atmospheric carbon dioxide reduction by Chicago's urban forest. In: McPherson, E.G., Nowak, D.J., Rowntree, R.A. (Eds.), Chicago's Urban Forest Ecosystem: Results of the Chicago Urban Forest ClimateProject. General Technical Report. Northeastern Forest Experiment Station186,pp. 83-94.

38. Myeong, S., Nowak, D. J., and Duggin, M. J. (2006). A temporal analysis of urban forest carbon storage using remote sensing. Remote Sens. Environ. 101, 277-282. doi: 10.1016/j.rse.2005.12.001

39. Nowak, D.J., Hoehn, R.E., Bodine, A.R., Greenfield, E.J., O'Neil-Dunne, J., 2013a. Urban forest structure, ecosystem services and change in Syracuse, NY. Urban Ecosyst. 1-23.

40. http://dx.doi.org/10.1007/s11252-013-0326-z.

41. Nowak, D.J., A.B. Cumming, D. Twardus, R.E. Hoehn, C.M. Oswalt, T.J. BrandeisUrban Forests of Tennessee, 2009, United States Department of Agriculture Forest Service General Technical Report SRS-149 (2012), p. 60

42. Nowak, D.J., Crane, D.E., Stevens, J.C., 2006. Air pollution removal by urban trees and shrubs in the United States. Urban For. Urban Green. 4 (3-4), 115-123.

43. Nowak, D.J., Crane, D.E., 2002. Carbon storage and sequestration by urban trees in the USA. Environ. Pollut. 116 (3), 381-389.

44. Nowak, D.J., Crane, D.E., Stevens, J.C., Ibarra, M., 2002a. Brooklyn's Urban Forest. General Technical Report NE-290. U.S. Department of Agriculture, Forest Service, Northeastern Research Station, Newtown Square, pp. 107.

45. Pearson TRH, Brown S and Ravindranath NH 2005. Integrating carbon benefits estimates into GEF Projects. 1-56.

46. Pickard, B.R., Daniel, J., Mehaffey, M., Jackson, L.E., Neale, A., 2015. EnviroAtlas: a new geospatial tool to foster ecosystem services science and resource management. Ecosyst. Serv. 14, 45-55. 
47. Rowntree, R.A. \&Nowak, D.J. (1991) Quantifying the role of urban forests in removing atmospheric carbon dioxide. Journal of Arboriculture, 17,269- 275.

48. Russo, A., Escobedo, F. J., Timilsina, N., Schmitt, A. O., Varela, S., \& Zerbe, S. (2014). Assessing urban tree carbon storage and sequestration in Bolzano, Italy TT - International Journal of Biodiversity Science, Ecosystem Services \& Management. International Journal of Biodiversity Science, Ecosystem Services \& Management, 10(1), 54-70. https://doi.org/10.1080/21513732.2013.873822

49. Selmi, W., Weber, C., Riviere, E., Blond, N., Mehdi, L., Nowak, D., 2016. Air pollution removal by trees in public green spaces in Strasbourg city, France. Urban For. Urban Green. 17 (2), 192-201.

50. Seto, K. C., Güneralp, B. \& Hutyra, L. R. Global forecasts of urban expansion to 2030 and direct impacts on biodiversity and carbon pools. P. Natl. Acad. Sci. USA 109, 16083-16088.

51. Sharma, R., Pradhan, L., Kumari, M., \& Bhattacharya, P. (2020). Assessment of Carbon Sequestration Potential of Tree Species in Amity University Campus Noida. In Environmental Sciences Proceedings (Vol. 3, No. 1, p. 52). Multidisciplinary Digital Publishing Institute.

52. Sheikh MA, Kumar M, Bussman RW and Todaria NP 2011. Forest carbon stocks and fluxes in physiographic zones of India. Carbon Balance Management 6: 15.

53. Speak, A. F., Mizgajski, A., \& Borysiak, J. (2015). Allotment gardens and parks: Provision of ecosystem services with an emphasis on biodiversity. Urban Forestry \& Urban Greening, 14(4), 772-781.

54. Stoffberg, G.H., van Rooyen, M.W., van der Linde, M.J., Groeneveld, H.T., 2010. Carbon sequestration estimates of indigenous street trees in the City of Tshwane South Africa. Urban Forestry and Urban Greening 9, 9-14.

55. Sun Y, Xie S, Zhao S. Valuing urban green spaces in mitigating climate change: A city-wide estimate of aboveground carbon stored in urban green spaces of China's Capital. Glob Change Biol. 2019;00:116. https://doi.org/10.1111/gcb.14566.

56. Tang, Y., Chen, A., \& Zhao, S. (2016). Carbon storage and sequestration of urban street trees in Beijing, China. Frontiers in Ecology and Evolution, 4(MAY). https://doi.org/10.3389/fevo.2016.00053

57. Tallis, H.T., Ricketts, T., Guerry, A.D., Nelson, E., Ennaanay, D., Wolny, S., Olwero, N., Vigerstol, K., Pennington, D., Mendoza, G., Aukema, J., Foster, J., Forrest, J., Cameron, D., Lonsdorf, E., Kennedy, C., Verutes, G., Kim, C.K., Guannel, G., Papenfus, M., Toft, J., Marsik, M., Bernhardt, J., 2011. InVEST 2.0 Beta User's Guide. The Natural Capital Project. (Stanford).

58. TEEB. (2010). The economics of ecosystems and biodiversity. Ecological and Economic Foundations. Earthscan London and Washington.

59. Tripathi, Mayank \& Joshi, and. (2015). Carbon flow in Delhi Urban Forest ecosystems. ANNALS OF BIOLOGICAL RESEARCH. 6. 13-17.

60. USDA Forest Service, 2015. i-Tree Eco Version 6.0.i-Tree Eco Version 6.0.

61. Vishnu, P., Patil, S.S., 2016. Carbon storage and sequestration by trees in and around university campus of Aurangabad City Maharashtra, International Journal of Innovative Research in Science. Eng. Technol. 5 (4), 5459-5468. http://dx.doi.org/10.15680/IJIRSET.2016.0504179. 
62. Yang, J., McBride, J., Zhou, J., Sun, Z., 2005. The urban forest in Beijing and its role in air pollution reduction. Urban Forestry and Urban Greening 3, 65-78.

63. Zhao, M., Kong, Z., Escobedo, F.J., Gao, J., 2010. Impacts of urban forests on offset- ting carbon emissions from industrial energy use in Hangzhou, China. Journal of Environmental Management 91, 807-813.

\section{Tables}

Table 1

Area covered by different forest class in Delhi

\begin{tabular}{|lll|}
\hline Class & Area (sq.km) & $\%$ of Delhi's Land \\
\hline Very Dense Forest (VDF) & 6.72 & 0.45 \\
\hline Moderately Dense Forest (MDF) & 56.42 & 3.81 \\
\hline Open Forest (OF) & 132.30 & 8.92 \\
\hline Total & 195.44 & 13.18 \\
\hline Source: ISFR, 2019 & & \\
\hline
\end{tabular}

Due to technical limitations, table 2 is only available as a download in the Supplemental Files section.

Table 1 Carbon Sequestered by Different Trees Species in GGS IP University Campus, Dwarka, Delhi 


\begin{tabular}{|c|c|c|c|c|c|c|c|}
\hline S.No. & $\begin{array}{l}\text { Scientific } \\
\text { Name }\end{array}$ & Family & $\begin{array}{l}\text { No. } \\
\text { of } \\
\text { Trees }\end{array}$ & AGB (kg) & BGB (kg) & TB (kg) & CS (kg) \\
\hline 1 & $\begin{array}{l}\text { Acacia } \\
\text { auriculiformis }\end{array}$ & Mimosaceae & 10 & 204.6 & 30.69 & 235.28 & 117.64 \\
\hline 2 & $\begin{array}{l}\text { Acacia } \\
\text { nilotica }\end{array}$ & Mimosaceae & 2 & 378.12 & 56.72 & 434.84 & 217.42 \\
\hline 3 & $\begin{array}{l}\text { Aegle } \\
\text { marmelos }\end{array}$ & Rutaceae & 2 & 104.04 & 15.61 & 119.65 & 59.82 \\
\hline 4 & $\begin{array}{l}\text { Albizia } \\
\text { lebbeck }\end{array}$ & Mimosaceae & 5 & 764.06 & 114.61 & 878.67 & 439.33 \\
\hline 5 & $\begin{array}{l}\text { Alstonia } \\
\text { scholaris }\end{array}$ & Apocynaceae & 44 & 8005.6 & 1200.84 & 9206.44 & 4603.22 \\
\hline 6 & $\begin{array}{l}\text { Azadirachta } \\
\text { indica }\end{array}$ & Meliaceae & 82 & 8326.51 & 1248.98 & 9575.49 & 4787.74 \\
\hline 7 & $\begin{array}{l}\text { Bauhinia } \\
\text { racemosa }\end{array}$ & Caesalpiniaceae & 2 & 20.17 & 3.03 & 23.2 & 11.6 \\
\hline 8 & $\begin{array}{l}\text { Bombax } \\
\text { ceiba }\end{array}$ & Bombacaceae & 38 & 9786.57 & 1467.99 & 11254.56 & 5627.28 \\
\hline 9 & $\begin{array}{l}\text { Callistemon } \\
\text { viminalis }\end{array}$ & Myrtaceae & 2 & 21.89 & 3.28 & 25.17 & 12.59 \\
\hline 10 & $\begin{array}{l}\text { Carica } \\
\text { papaya }\end{array}$ & Caricaceae & 1 & 13.82 & 2.07 & 15.89 & 7.95 \\
\hline 11 & Caryota urens & Arecaceae & 1 & 281.61 & 42.24 & 323.85 & 161.93 \\
\hline 12 & Cassia fistula & Caesalpiniaceae & 20 & 773.23 & 115.98 & 889.21 & 444.61 \\
\hline 13 & $\begin{array}{l}\text { Cordia } \\
\text { dichotoma }\end{array}$ & Boraginaceae & 2 & 195.76 & 29.36 & 225.13 & 112.56 \\
\hline 14 & $\begin{array}{l}\text { Dalbergia } \\
\text { sissoo }\end{array}$ & Fabaceae & 44 & 4855.3 & 728.3 & 5583.6 & 2791.8 \\
\hline 15 & Delonix regia & Caesalpiniaceae & 8 & 869.58 & 130.44 & 1000.02 & 500.01 \\
\hline 16 & $\begin{array}{l}\text { Ficus } \\
\text { benghalensis }\end{array}$ & Moraceae & 15 & 8672.03 & 1300.8 & 9972.84 & 4986.42 \\
\hline 17 & $\begin{array}{l}\text { Ficus } \\
\text { benjamina }\end{array}$ & Moraceae & 334 & 47374.67 & 7106.2 & 54480.87 & 27240.44 \\
\hline 18 & $\begin{array}{l}\text { Ficus } \\
\text { religiosa }\end{array}$ & Moraceae & 25 & 14620.99 & 2193.15 & 16814.14 & 8407.07 \\
\hline 19 & Ficus virens & Moraceae & 569 & 76385.89 & 11457.88 & 87843.78 & 43921.89 \\
\hline 20 & $\begin{array}{l}\text { Grevillea } \\
\text { robusta }\end{array}$ & Proteaceae & 10 & 365.24 & 54.79 & 420.03 & 210.01 \\
\hline
\end{tabular}




\begin{tabular}{|c|c|c|c|c|c|c|c|}
\hline 21 & $\begin{array}{l}\text { Jacaranda } \\
\text { mimosifolia }\end{array}$ & Bignoniaceae & 2 & 167.99 & 25.2 & 193.19 & 96.59 \\
\hline 22 & $\begin{array}{l}\text { Kigelia } \\
\text { africana }\end{array}$ & Bignoniaceae & 7 & 1011.9 & 151.79 & 1163.69 & 581.84 \\
\hline 23 & $\begin{array}{l}\text { Leucacena } \\
\text { leucocephala }\end{array}$ & Mimosaceae & 6 & 244.67 & 36.7 & 281.37 & 140.68 \\
\hline 24 & $\begin{array}{l}\text { Melia } \\
\text { azedarach }\end{array}$ & Meliaceae & 14 & 1778.87 & 266.83 & 2045.7 & 1022.85 \\
\hline 25 & $\begin{array}{l}\text { Mimusops } \\
\text { elengi }\end{array}$ & Sapotaceae & 7 & 81.41 & 12.21 & 93.62 & 46.81 \\
\hline 26 & $\begin{array}{l}\text { Moringa } \\
\text { oleifera }\end{array}$ & Moringaceae & 9 & 644.45 & 96.67 & 741.11 & 370.56 \\
\hline 27 & Morus alba & Moraceae & 51 & 6304.87 & 945.73 & 7250.6 & 3625.3 \\
\hline 28 & $\begin{array}{l}\text { Phyllanthus } \\
\text { emblica }\end{array}$ & Phyllanthaceae & 4 & 150.95 & 22.64 & 173.59 & 86.79 \\
\hline 29 & $\begin{array}{l}\text { Plumeria } \\
\text { rubra }\end{array}$ & Apocynaceae & 15 & 204.45 & 30.67 & 235.11 & 117.56 \\
\hline 30 & $\begin{array}{l}\text { Polyalthia } \\
\text { longifolia }\end{array}$ & Annonaceae & 48 & 1349.57 & 202.44 & 1552.01 & 776 \\
\hline 31 & $\begin{array}{l}\text { Pongamia } \\
\text { pinnata }\end{array}$ & Fabaceae & 17 & 413.71 & 62.06 & 475.76 & 237.88 \\
\hline 32 & Erythrina spp. & Fabaceae & 10 & 109.64 & 16.45 & 126.09 & 63.05 \\
\hline 33 & $\begin{array}{l}\text { Psidium } \\
\text { guajava }\end{array}$ & Myrtaceae & 5 & 71.14 & 10.67 & 81.81 & 40.91 \\
\hline 34 & $\begin{array}{l}\text { Putranjiva } \\
\text { roxburghii }\end{array}$ & Putranjivaceae & 134 & 13149.76 & 1972.46 & 15122.22 & 7561.11 \\
\hline 35 & $\begin{array}{l}\text { Roystonea } \\
\text { regia }\end{array}$ & Arecaceae & 1 & 30.9 & 4.64 & 35.54 & 17.77 \\
\hline 36 & $\begin{array}{l}\text { Senna } \\
\text { siamea }\end{array}$ & Caesalpiniaceae & 28 & 5562.26 & 834.34 & 6396.6 & 3198.3 \\
\hline 37 & $\begin{array}{l}\text { Spathodea } \\
\text { campanulata }\end{array}$ & Bignoniaceae & 38 & 1282.17 & 192.33 & 1474.5 & 737.25 \\
\hline 38 & $\begin{array}{l}\text { Syzygium } \\
\text { cumini }\end{array}$ & Myrtaceae & 3 & 60.7 & 9.1 & 69.8 & 34.9 \\
\hline 39 & $\begin{array}{l}\text { Terminalia } \\
\text { arjuna }\end{array}$ & Combretaceae & 37 & 1004.19 & 150.63 & 1154.82 & 577.41 \\
\hline 40 & $\begin{array}{l}\text { Ziziphus } \\
\text { mauritiana }\end{array}$ & Rhamnaceae & 5 & 263.55 & 39.53 & 303.08 & 151.54 \\
\hline
\end{tabular}




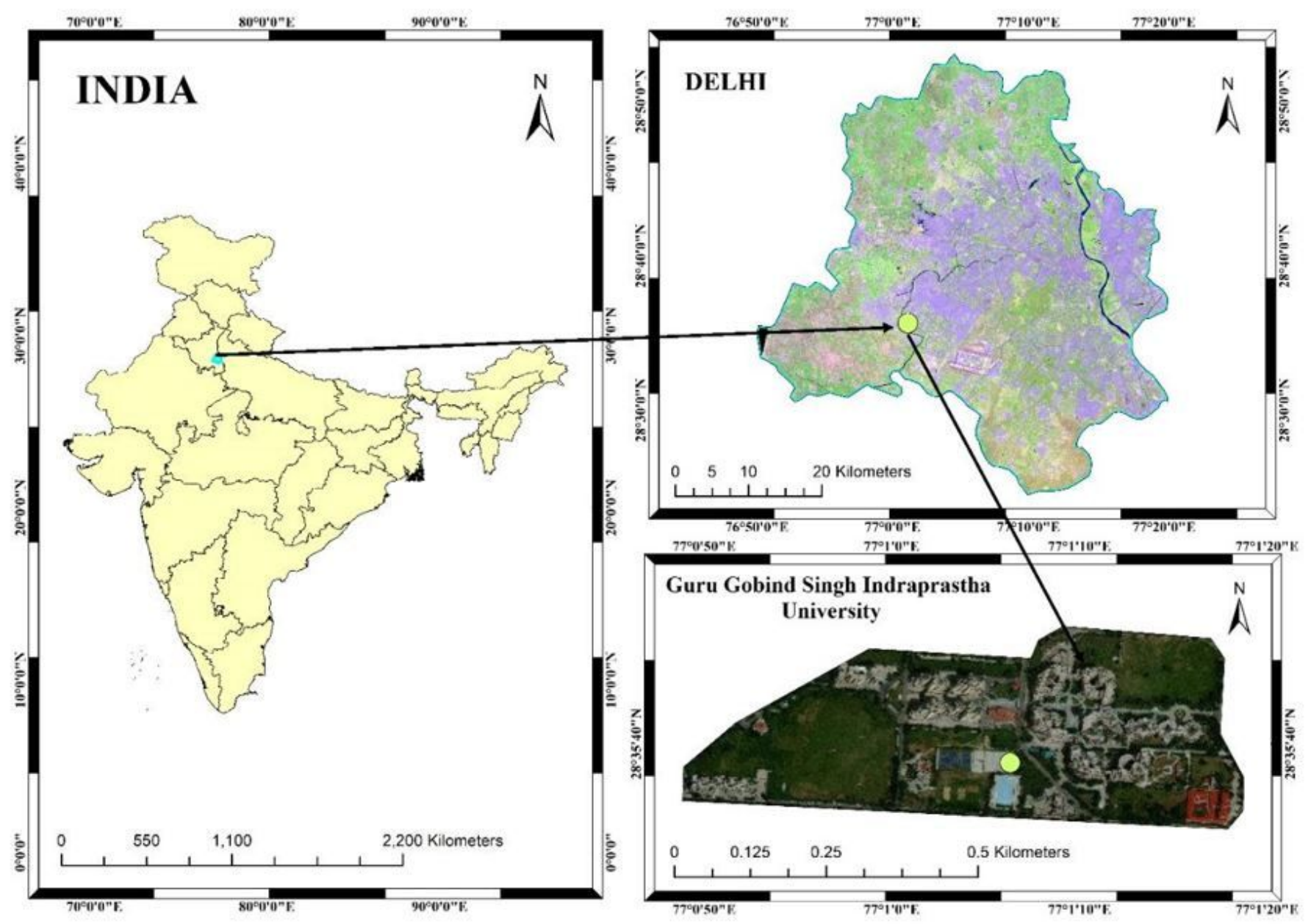

Figure 1

Location of Guru Gobind Singh Indraprastha University, Delhi Note: The designations employed and the presentation of the material on this map do not imply the expression of any opinion whatsoever on the part of Research Square concerning the legal status of any country, territory, city or area or of its authorities, or concerning the delimitation of its frontiers or boundaries. This map has been provided by the authors. 


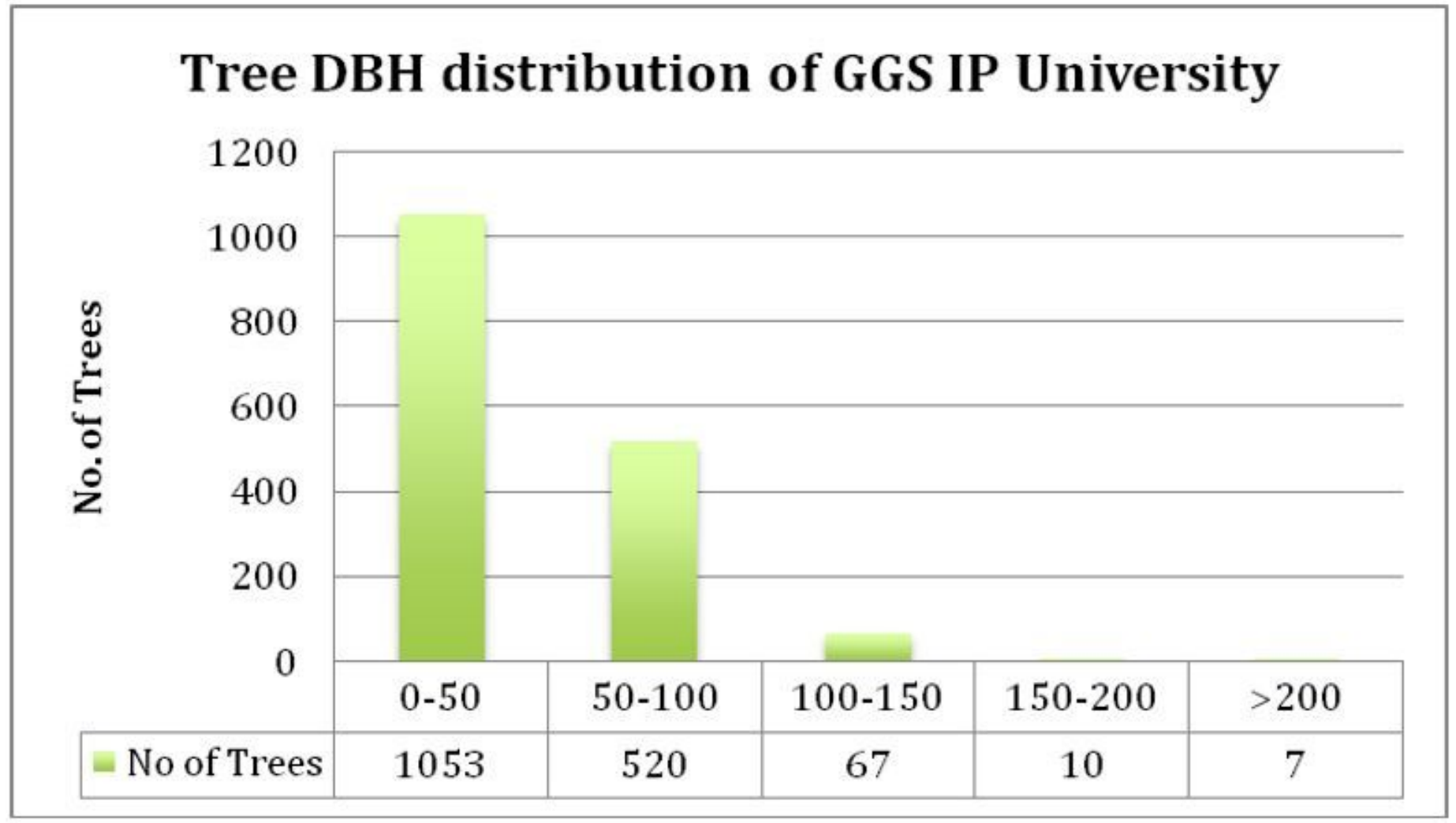

Figure 2

Distribution of trees on the basis of $\mathrm{DBH}$

\section{Carbon Sequestration by Trees Species}

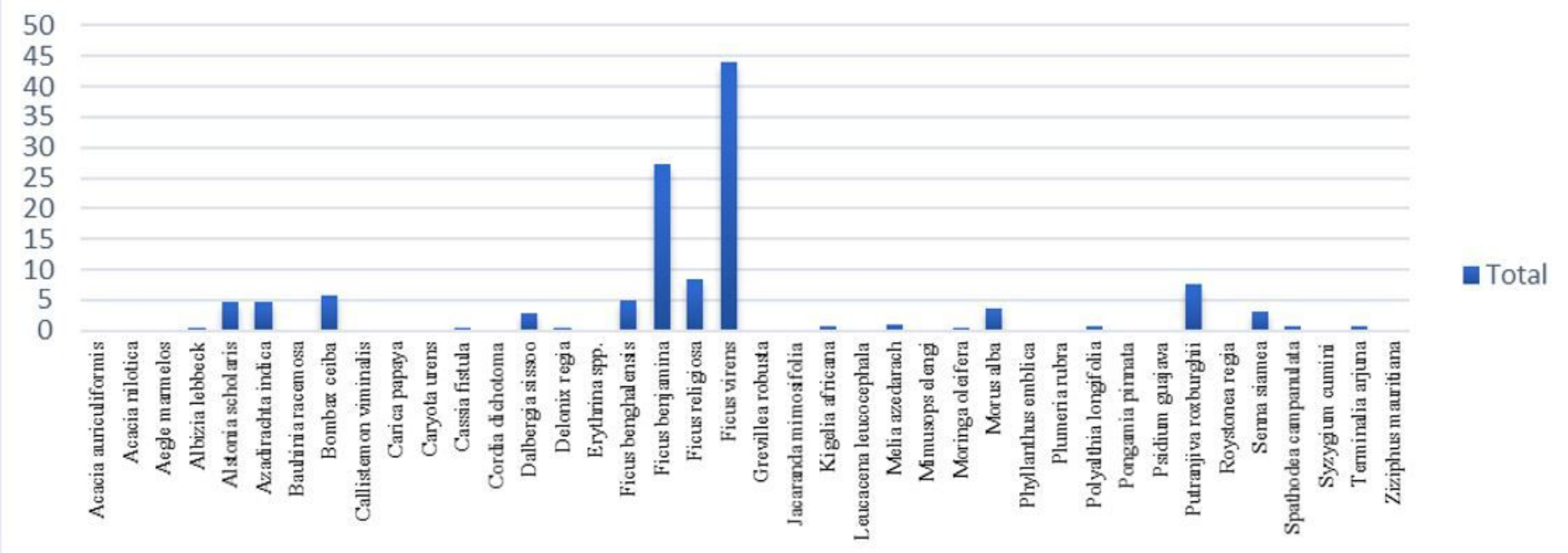

Figure 3

Carbon Sequestered by Tree Species at GGS IP University, Dwarka, Delhi 


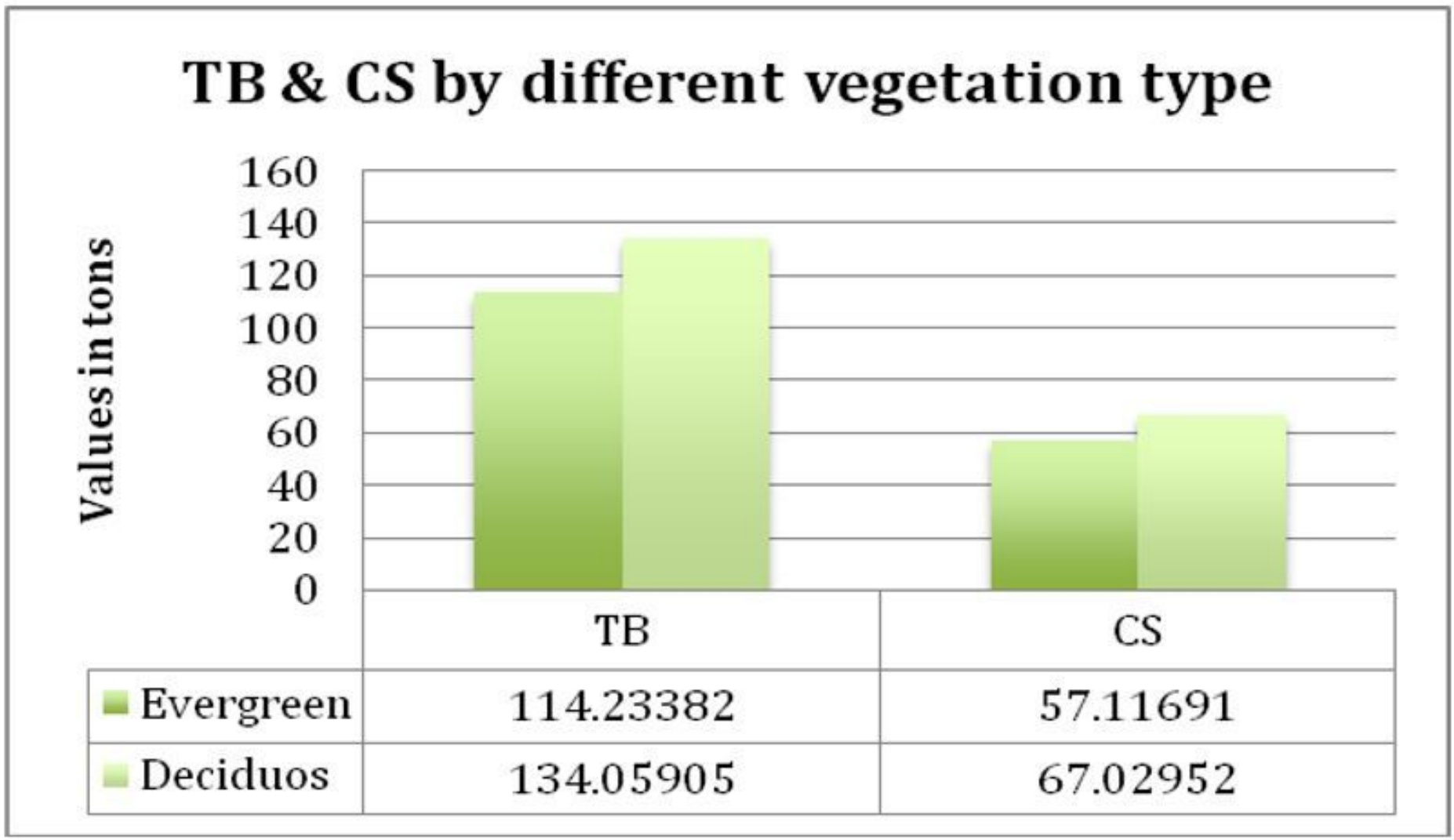

Figure 4

Total Biomass \& Carbon Storage by different Vegetation Type 


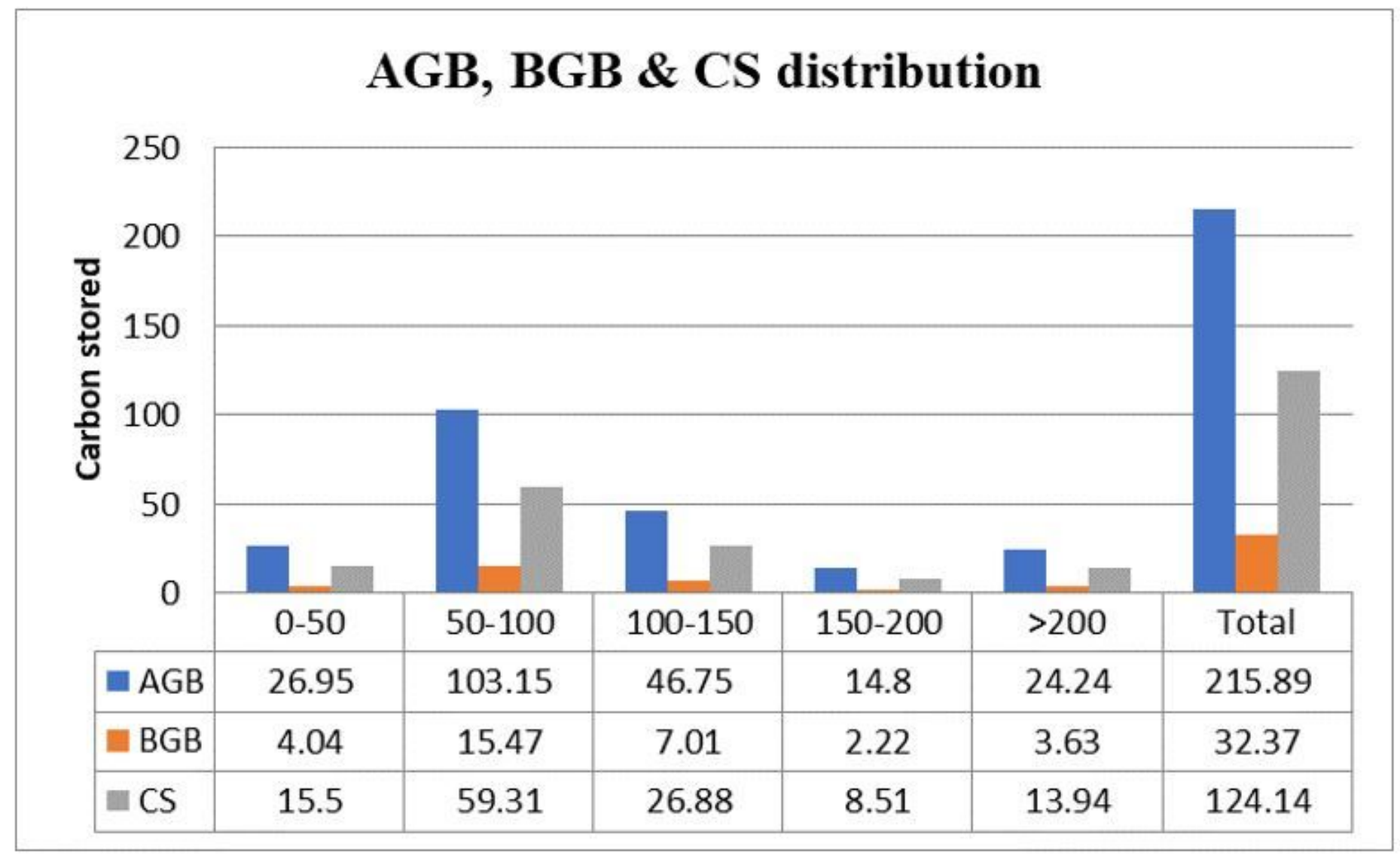

Figure 5

Above \& Below Ground Biomass \& Carbon Storage Distribution

\section{Supplementary Files}

This is a list of supplementary files associated with this preprint. Click to download.

- Table2.jpg 